\title{
NC1404, a novel derivative of Bleomycin with modified sugar moiety obtained during the preparation of Boningmycin
}

\author{
Xin Qi, Xinwei Wang, Hao Ren, Feng Zhang, Xiumin Zhang, Ning He, Wenqiang Guo, Ruxian Chen, \\ Yunying Xie and Qiyang He
}

The Journal of Antibiotics (2017) 70, 970-973; doi:10.1038/ja.2017.63; published online 31 May 2017

\begin{abstract}
Boningmycin, isolated from the fermentation broth of Streptomyces verticillus var. pingyangensis $\mathrm{n}$. var, ${ }^{1}$ is a member of Bleomycins, which are glycopeptide anticancer antibiotics and widely used in clinical applications for various tumors such as squamous cell carcinomas, germ cell tumors, lymphoma and malignant pleural effusion. ${ }^{2-4}$ According to the results of the structure-activity relationship, the molecules of Bleomycins can be divided into three main characterized parts: (1) the metal-binding domain that combines with metal ions and oxygen to form an active complex responsible for DNA cleavage, ${ }^{5,6}$ (2) the bithiazole tail that facilitates the Bleomycins binding to nucleic acids and (3) the D-mannosyl-L-gulose moiety that plays a yet unclear role. ${ }^{7,8}$ Recently, one research showed that the sugar moiety of the Bleomycins plays a significant role in Bleomycins' tumor cell targeting, ${ }^{9}$ while another report suggested that it is not quite essential for the antitumor activity of Bleomycins, but critical for its toxicity. ${ }^{10}$ During our research of Boningmycin, a compound NC1404 with modified sugar moiety was obtained and showed lower toxicity and comparable antitumor activity with Boningmycin, which may provide an additional proof of the toxicity of the sugar moiety of Bleomycins. Here we report on the production, isolation, structural elucidation, antitumor activity and primary toxicity of NC1404.

The strain was cultivated on an agar slant containing glucose $1.0 \%$, soluble starch $1.0 \%$, peptone $0.5 \%$, agar $2.0 \%$ and $\mathrm{NaCl} 0.5 \%$ $(\mathrm{pH} 7.2-7.5)$ at $28^{\circ} \mathrm{C}$ for 7 days, then inoculated in $250 \mathrm{ml}$ Erlenmeyer flasks containing $50 \mathrm{ml}$ of the production medium (soluble starch $2.5 \%$, glucose $0.5 \%$, soybean meal $3.5 \%, \mathrm{KH}_{2} \mathrm{PO}_{4}$ $0.1 \%, \mathrm{ZnSO}_{4} 0.05 \%$ and $\mathrm{CuSO}_{4} 0.01 \%(\mathrm{pH} 6.0-6.5)$ ) and incubated at $28^{\circ} \mathrm{C}$ on a rotary shaker (220 r.p.m.) for $48 \mathrm{~h}$. Subsequently, $10 \mathrm{ml}$ of obtained preculture was transferred into $500 \mathrm{ml}$ Erlenmeyer flasks containing $100 \mathrm{ml}$ of the production medium. The fermentation was carried out at $28^{\circ} \mathrm{C}$ on a rotary shaker at 220 r.p.m. for 7 days. The copper-chelated Boningmycin was isolated from the fermentation broth according to the reported method with minor modifications. ${ }^{11}$ Briefly, the fermentation broth (201) was adjusted to $\mathrm{pH} 2 \sim 3$ with
\end{abstract}

oxalic acid and filtered. The boningmycin was enriched from the filtrate by macroporous abosorben resin 4006 column (2 l, The Chemical Plant of NanKai University). The obtained crude material was chromatographed on a column of CM-Sephadex C-25 $\left(\mathrm{NH}_{4}{ }^{+}\right.$form, $200 \mathrm{ml}, \mathrm{H} \& \mathrm{E}$ Co., Ltd, Beijing, China), and eluted with a stepwise gradient of $\mathrm{NH}_{4} \mathrm{Cl}$ solution $(0.1-0.6 \mathrm{M})$. As a result, copperchelated Boningmycin was purified. The solution was combined, desalted, concentrated and lyophilized to yield a blue powder $(1155 \mathrm{mg})$. Then, the obtained blue powder was treated with dithizone $(165 \mathrm{mg})$ in $\mathrm{MeOH}(37.5 \mathrm{ml})$. The solution was filtered, and the filtrate was precipitated with four times the volume of $\mathrm{Me}_{2} \mathrm{CO}$. After washed with acetone for three times and filtered, the precipitate was dissolved in distilled water and applied on the column of CMSephadex C-25 $\left(\mathrm{NH}_{4}{ }^{+}\right.$form, $\left.160 \mathrm{ml}\right)$, subsequently eluted with a stepwise gradient of $\mathrm{NH}_{4} \mathrm{Cl}$ solution from 0.1 to $0.4 \mathrm{M}$. As a result, two compounds Boningmycin $(787.5 \mathrm{mg})$ and $\mathrm{NC1} 104(15 \mathrm{mg})$ were obtained.

Compound NC1404 was a white powder with a molecular weight of 1578.44 based on ESI-MS spectrum (Supplementary Figure S1), which gave three quasi-molecular ions at $\mathrm{m} / \mathrm{z} 1579.44[\mathrm{M}+\mathrm{H}]^{+}, 790.54$ $[\mathrm{M}+2 \mathrm{H}]^{2+}$ and $528.01[\mathrm{M}+3 \mathrm{H}]^{3+}$. The molecular weight of $\mathrm{NC1} 404$ was 40 units larger than that of Boningmycin. The fragment ions at $\mathrm{m} / \mathrm{z} 688.07$ [M-Carbamylmannose $+\mathrm{H}]^{2+}$ indicated that NC1404 has the same carbarmylannose part as Boningmycin. But the fragment ions at $\mathrm{m} / \mathrm{z} 587.00[\mathrm{M} \text {-Carbamylmannose-gulosyl }+\mathrm{H}]^{2+}$ showed that the gulosyl part of the $\mathrm{NC1404}$ was 40 units larger than that of Boningmycin, which implied that NC1404 is structurally the same as boningmycin except the gulosyl part.

Despite the spectral complexities, the ${ }^{1} \mathrm{H}$ NMR spectrum of NC1404 showed characteristic four aromatic proton signals at $\delta_{\mathrm{H}}$ 7-9 p.p.m. which belonged to the thiazole ring and imidazole ring of the Bleomycin, indicative of the same kernel structure of NC1404 and Bleomycin as well as Boningmycin. ${ }^{1,12}$ The ${ }^{13} \mathrm{C}$ NMR data of NC1404 were tabulated in Table 1 in comparison with those of 
Table $1{ }^{13} \mathrm{C}$ NMR data of NC1404 and boningmycin $\left(600 \mathrm{MHz}, \mathrm{D}_{2} \mathrm{O}\right)$

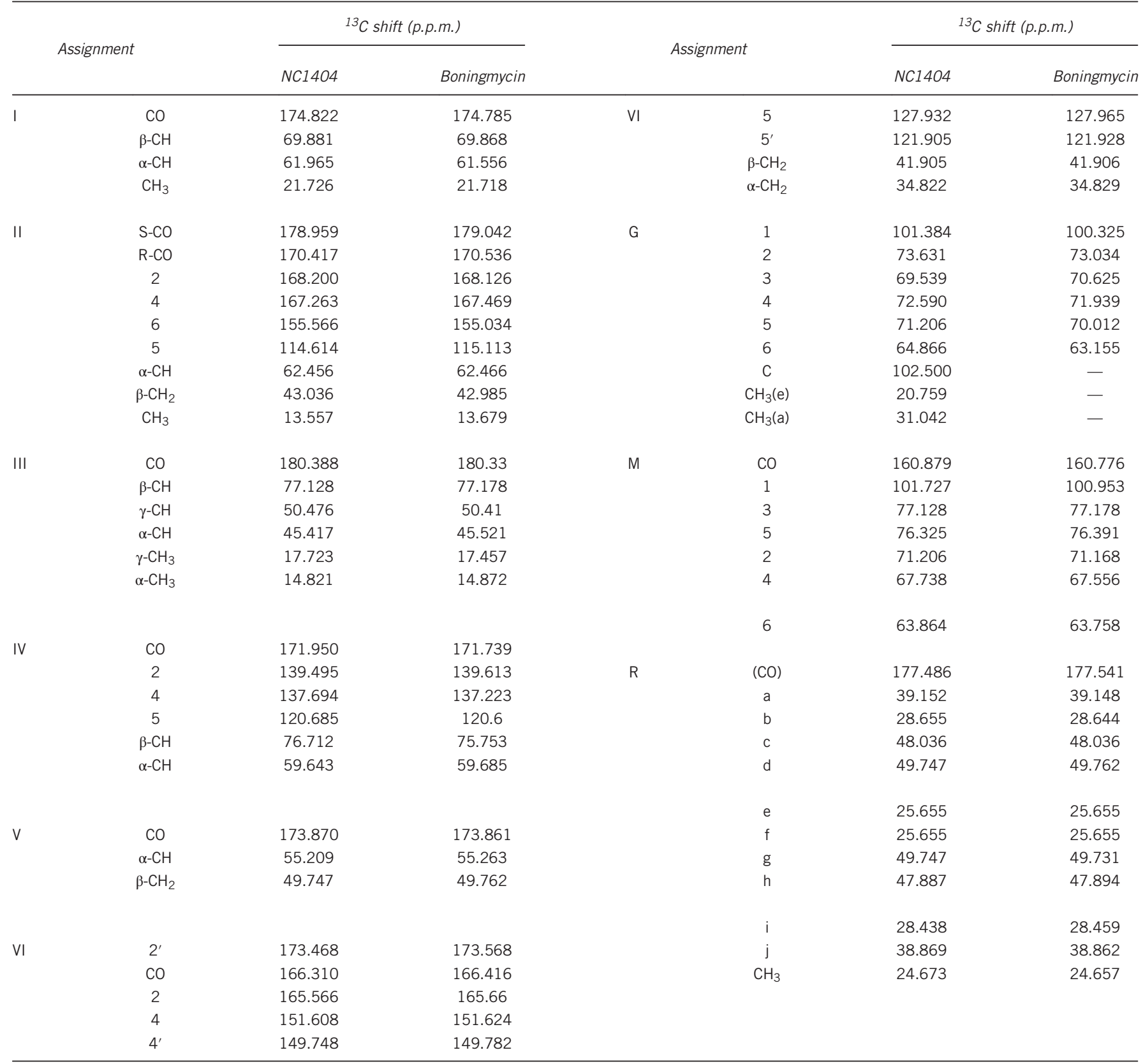

Boningmycin and analysis of ${ }^{1} \mathrm{H}-{ }^{1} \mathrm{H}$ COSY, HSQC, DEPT and HMBC spectra. ${ }^{13}$ The numbering of the parts in the NC1404 molecule follows the convention used in the previous papers as shown in Figure 1. The signals of the carbons constituting the kernel structure and terminal amine of $\mathrm{NC1} 404$ are consistent with those of Boningmycin and the only difference is that $\mathrm{NC1404}$ had three extra carbon signals $\delta_{\mathrm{C}} 102.500(\mathrm{G}-\mathrm{C}), \delta_{\mathrm{C}} 20.759\left(\mathrm{G}-\mathrm{CH}_{3}(\mathrm{e})\right)$ and $\delta_{\mathrm{C}} 31.042\left(\mathrm{G}-\mathrm{CH}_{3}(\mathrm{a})\right)$, which implied that there was an isopropylidene acetal group in the structure of $\mathrm{NC1404}$. In addition, the $\mathrm{HMBC}$ correlations from $\delta_{\mathrm{H}} 1.482\left(\mathrm{G}-\mathrm{CH}_{3}(\mathrm{e})\right)$ and $\delta_{\mathrm{H}} 1.377\left(\mathrm{G}-\mathrm{CH}_{3}(\mathrm{a})\right)$ to $\delta_{\mathrm{C}} 102.500(\mathrm{G}-\mathrm{C})$, $\delta_{\mathrm{H}} 1.377\left(\mathrm{G}-\mathrm{CH}_{3}(\mathrm{a})\right)$ to $\delta_{\mathrm{c}} 20.759$ confirmed the above hypothesis. Furthermore, the signal at $\delta_{\mathrm{H}} 1.377\left(\mathrm{G}-\mathrm{CH}_{3}(\mathrm{a})\right)$ showed weak coupling to $\delta_{\mathrm{C}} 64.866(\mathrm{G}-6)$ and $\delta_{\mathrm{C}} 72.590(\mathrm{G}-4), \delta_{\mathrm{H}} 3.364$ (G-6) to $\delta_{\mathrm{C}} 102.510(\mathrm{G}-\mathrm{C})$, which suggested that the isopropylidene acetal group linked to hydroxyl groups of gulosyl moiety $(\mathrm{G})$ at the site of G-6 and G-4 (Figure 2). Comprehensive interpretation of ${ }^{1} \mathrm{H}$ NMR, ${ }^{13} \mathrm{C}$ NMR, ${ }^{1} \mathrm{H}_{-}{ }^{1} \mathrm{H}$ COSY, HSQC, DEPT and HMBC spectra of NC1404 further confirmed the expected structure (Figure 1a).

NC1404 may be an artifact deriving from Boningmycin with acetone during the process of decoppering. To prove this, Boningmycin was dissolved in methanol, four-fold volume of acetone was added into the solvent and a small amount of hydrochloric acid was added dropwise under stirring to form a large amount of precipitate. The precipitate was analyzed by HPLC (performed on an SHIMADZU $10 \mathrm{~A}$ instrument using an ZORBAX Eclipse Plus C18 column $(4.6 \times 250 \mathrm{~mm}, 5 \mu \mathrm{m})$ on a binary LC system (solvent A: $80 \mathrm{~mm}$ acetic 


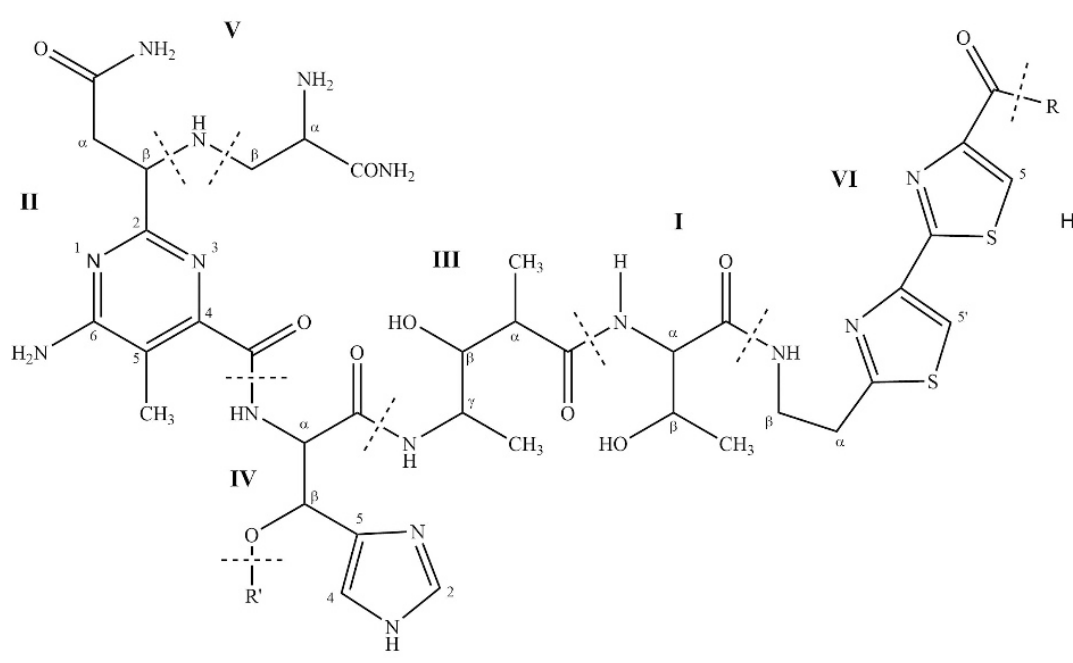

$\mathrm{NC} 1404$ $\mathrm{R}^{\prime}=\mathrm{a} \quad \mathrm{R}=\mathrm{NHCH}_{2} \mathrm{CH}_{2} \mathrm{CH}_{2} \mathrm{NHCH}_{2} \mathrm{CH}_{2} \mathrm{CH}_{2} \mathrm{CH}_{2} \mathrm{NHCH}_{2} \mathrm{CH}_{2} \mathrm{CH}_{2} \mathrm{NHCOCH}_{3}$ Boningmycin $\quad \mathrm{R}^{\prime}=\mathbf{b} \quad \mathrm{R}=\mathrm{NHCH}_{2} \mathrm{CH}_{2} \mathrm{CH}_{2} \mathrm{NHCH}_{2} \mathrm{CH}_{2} \mathrm{CH}_{2} \mathrm{CH}_{2} \mathrm{NHCH}_{2} \mathrm{CH}_{2} \mathrm{CH}_{2} \mathrm{NHCOCH}_{3}$

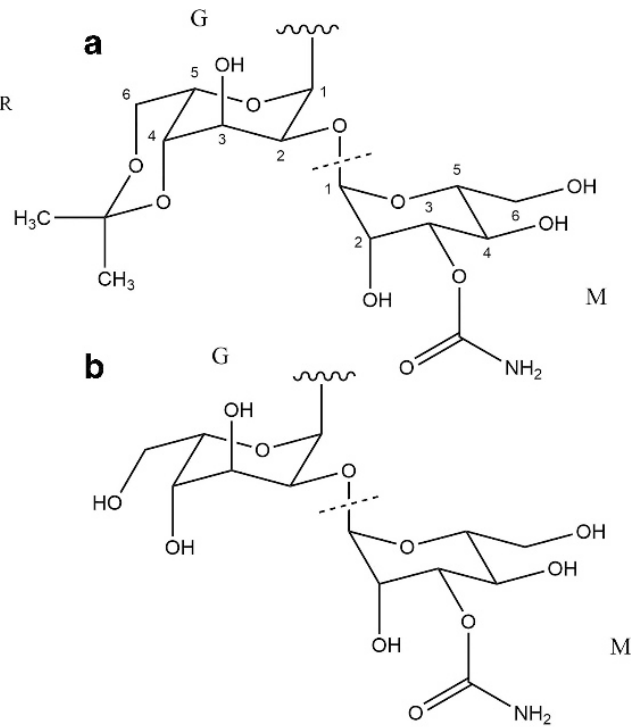

$\mathrm{G}=\mathrm{a}-\mathrm{L}-\mathrm{Gulose}$ $\mathrm{M}=\alpha \quad-\mathrm{D}-\mathrm{Mannose}$

Figure 1 The Structures of NC1404 and Boningmycin.

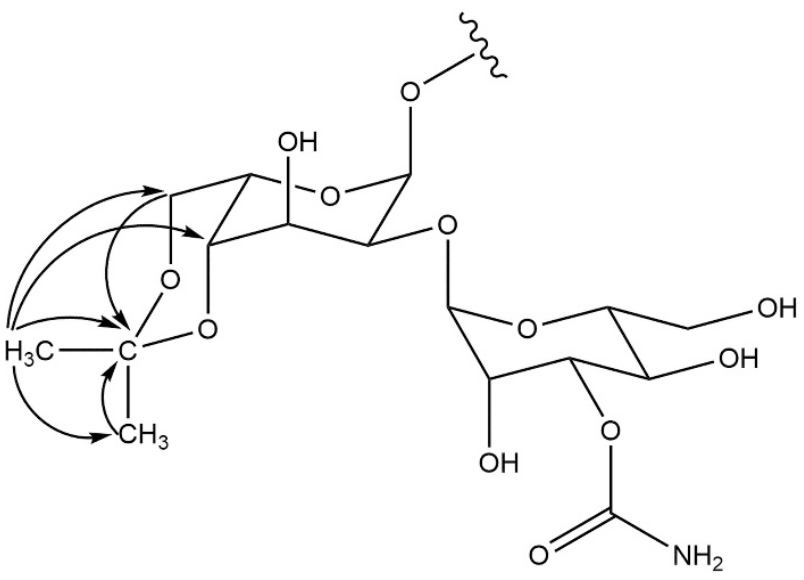

Figure 2 Selective HMBC correlations of the sugar moiety of NC1404.

Table 2 Activities $\left(\mathrm{IC}_{50}, \mu \mathrm{M}\right)$ of $\mathrm{NC} 1404$ in inhibiting the growth of cultured tumor cells

\begin{tabular}{lccc}
\hline Cell line & NC1404 & Boningmycin & Bleomycin \\
\hline HepG2 & $1.34 \pm 0.10$ & $1.41 \pm 0.06$ & $2.96 \pm 0.34$ \\
HeLa & $3.06 \pm 0.32$ & $2.76 \pm 0.28$ & $4.22 \pm 0.29$ \\
HaCaT & $3.52 \pm 0.16$ & $4.18 \pm 0.08$ & $5.11 \pm 0.27$ \\
MCF7 & $1.70 \pm 0.47$ & $1.64 \pm 0.18$ & $2.25 \pm 0.45$ \\
HCT116(p53--) & $0.97 \pm 0.09$ & $1.03 \pm 0.13$ & $1.93 \pm 0.30$ \\
HCT116 & $0.77 \pm 0.05$ & $1.05 \pm 0.16$ & $1.55 \pm 0.07$ \\
\hline
\end{tabular}

acid and $40 \mathrm{~mm}$ sodium 1-hexanesulfonate aqueous solution, adjusted with ammonia to a $\mathrm{pH}$ of 3.8 , solvent $\mathrm{B}$ : methanol: acetonitrile $(70: 30 \mathrm{v} / \mathrm{v})$; flow rate $1 \mathrm{ml} \mathrm{min}^{-1} ; 60 \% \mathrm{~A}, 40 \% \mathrm{~B}$; UV detection at $254 \mathrm{~nm}$ and oven temperature at $30^{\circ} \mathrm{C}$ )). As a result, the formation of NC1404 was detected as shown in Supplementary

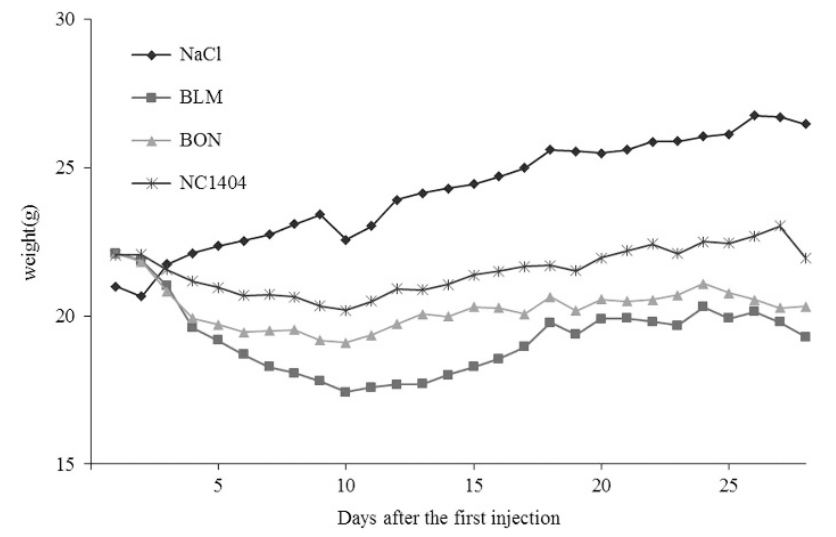

Figure 3 C57BL/6J mice's weight after injection of Bleomycin, Boningmycin, NC1404, and $\mathrm{NaCl}$. The abbreviations are as follows: $\mathrm{BLM}=$ Bleomycin, and $\mathrm{BON}=$ Boningmycin $\mathrm{A}$ full color version of this figure is available at the Journal of Antibiotics online.

Figure S7, which confirmed the speculation that NC1404 is an artifact during the process of decoppering.

To assess whether the modification in sugar moiety of NC1404 has an effect on the antitumor activity, an MTT assay was carried out using the reported method. ${ }^{14}$ The $\mathrm{IC}_{50}$ values of NC1404, Boningmycin and Bleomycin against HepG2, HeLa, HaCaT, MCF-7, HCT116 (p53-/-), HCT116 cells were listed in the Table 2, which showed that NC1404 had comparable antitumor activity with Boningmycin, but higher potency than Bleomycin.

Then, we evaluated the primary toxicity of NC1404 by comparing the effect of NC1404, Bleomycin and Boningmycin on the body weights of $\mathrm{C} 57 \mathrm{BL} / 6 \mathrm{~J}$ mice. The experiment had carried out that $12 \mathrm{mg} \mathrm{kg}^{-1}$ per day of the test compounds were i.p. daily for seven days and then observed the loss of the body weights for 28 days. In contrast to the control group, all the compound-injected groups 
showed the weight loss. However, the weights of NC1404 group mice reduced significantly less than that of the other groups (Figure 3 ).

\section{CONFLICT OF INTEREST}

The authors declare no conflict of interest.

\section{ACKNOWLEDGEMENTS}

We acknowledge financial support from the National Natural Science Foundation of China (81273415 and 81273553) and National Mega-project for Innovative Drugs (2012ZX09301002-001-023) and Institute of Medicinal Biotechnology foundation (2016ZX350045 and 2016ZX350053).

1 Umezawa, H., Maeda, K., Takeuchi, T. \& Okami, Y. New antibiotics, bleomycin A and B. J. Antibiot. (Tokyo) 19, 200-209 (1966).

2 Mir, L. M., Tounekti, O. \& Orlowski, S. Bleomycin: revival of an old drug. Gen. Pharmacol. 27, 745-748 (1996).

3 Fyfe, A. J. \& McKay, P. Toxicities associated with bleomycin. J. R. Coll. Physicians Edinb. 40, 213-215 (2010).
4 Bayer, R. A., Gaynor, E. R. \& Fisher, R. I. Bleomycin in non-Hodgkin's lymphoma. Semin. Oncol. 19, 46-52 (1992).

5 Sausville, E. A., Peisach, J. \& Horwitz, S. B. Effect of chelating agents and metal ions on the degradation of DNA by bleomycin. Biochemistry 17, 2740-2746 (1978).

6 Sausville, E. A., Stein, R. W., Peisach, J. \& Horwitz, S. B. Properties and products of the degradation of DNA by bleomycin and iron(II). Biochemistry 17 2746-2754 (1978)

7 Chen, J. \& Stubbe, J. Bleomycins: towards better therapeutics. Nat. Rev. Cancer. 5, 102-112 (2005).

8 Lehmann, T. E. \& Li, Y. Possible structural role of the disaccharide unit in Fe-bleomycin before and after oxygen activation. J. Antibiot. 65, 25-33 (2012).

$9 \mathrm{Yu}, \mathrm{Z}$. et al. Selective tumor cell targeting by the disaccharide moiety of bleomycin. J Am. Chem. Soc. 135, 2883-2886 (2013).

10 Burgy, 0. et al. Deglycosylated bleomycin has the antitumor activity of bleomycin without pulmonary toxicity. Sci. Transl. Med. 8, 326ra320 (2016).

11 Chen, C. et al. Isolation and characterization of antibiotic NC0604, a new analogue of bleomycin. J. Antibiot. 61, 747-751 (2008).

12 Naganawa, H., Muraoka, Y., Takita, T. \& Umezawa, H. Chemistry of bleomycin. XVIII. carbon-13 NMR studies. J. Antibiot. 30, 388-396 (1977).

13 Lehmann, T. E., Li, Y. \& Armstrong, G. S. NMR study of peplomycin in aqueous solution. Assignment of resonances by means of two-dimensional spectroscopy. J. Antibiot. 64, 309-316 (2011).

14 Boiko la, I., Suvorova, V. V., Timchenko, I. B. \& Golukhova, A. G. Rapid application of therapeutic-prophylactic orthoses using devices of polymer materials. Ortop. Travmatol. Protez. 59-61 (1983).

Supplementary Information accompanies the paper on The Journal of Antibiotics website (http://www.nature.com/ja) 